Pesq. Vet. Bras. 31(3):261-266, março 2011

\title{
Comparative anatomy of the thigh nerves of Cebus libidinosus (Rylands et al., 2000) ${ }^{1}$
}

\author{
Roqueline A.G.M.F. Aversi-Ferreira ${ }^{2,3}$, Kliver A. Marin²,3, Frederico O. \\ Carneiro e Silva ${ }^{3}$ and Tales A. Aversi-Ferreira ${ }^{2^{*}}$
}

\begin{abstract}
Aversi-Ferreira R.A.G.M.F., Marin K.A., Carneiro e Silva F.O. \& AversiFerreira T.A.A. 2011. Comparative anatomy of the thigh nerves of Cebus libidinosus (Rylands et al., 2000). Pesquisa Veterinária Brasileira 31(3):261-266. Departamento de Enfermagem, Universidade Federal de Goiás, Av. Dr. Lamartine Pinto de Avelar 1120, Catalão, GO 75704-020, Brazil. E-mail: aversiferreira@gmail.com

Non-human primates have constituted an important group among animals subjected to various studies. Ethological, evolutionary and paleontological studies have revealed changes in anatomical structures linked to the evolution of primates, considered in studies on the comparative anatomy between Cebus libidinosus and other neotropical monkeys or those from the Old World, and the detailed knowledge on their anatomy may represent an important factor for their preservation and protection when the animals are brought to veterinary clinics after accidents or illnesses. In terms of veterinary importance, sometimes these animals arrive in the veterinary medical clinics after accidents, needing surgery or clinical treatment, but the little data available on anatomy has impaired the correct proceedings. The main justification for studies on $C$. libidinosus, is due to little information about the anatomy related to $C$. libidinosus in Brazilian and worldwide scientific literature. In this study, the distribution, enervation and path of the femoral and sciatic nerves of the pelvic limb (thigh) of C. libidinosus were studied and these results were compared with literature on the anatomy of humans, chimpanzees and baboons. In general, the enervation model of the four primates is identical, but in specific terms, the differences in enervations indicate evolution convergence closer to the branch of baboons in the evolutionary tree, and these data corroborate other comparative studies in relation to the same primates to vessels, muscles and nerves. In conclusion, the nerve organization in the thigh of $C$. libidinosus is identical to baboon, chimpanzee and homo, but more similar to baboon. The specific differences found indicate an ancient phylogenic origin to $C$. libidinosus and baboons (data corroborated by other studies).
\end{abstract}

INDEX TERMS: Cebus libidinosus, comparative anatomy, capuchin monkey, thigh nerves, pelvic limbs.

RESUMO.- [Anatomia comparativa dos nervos da coxa de Cebus libidinosus (Rylands et al., 2000).] Primatas não-humanos têm constituído um importante grupo entre os animais submetidos a vários estudos. Estudos etológicos, evolutivos e paleontológicos revelaram alterações das

\footnotetext{
${ }^{1}$ Received on March 8, 2010.

Accepted for publication on January 20, 2011.

2 Laboratório de Neurociências e Comportamento de Primatas (NECOP), Universidade Federal de Goiás (UFG), Av. Dr. Lamartine Pinto de Avelar 1120, Catalão, GO 75704-020, Brazil. *Corresponding author: aversiferreira@gmail.com

${ }^{3}$ Faculdade de Medicina Veterinária, Universidade Federal de Uberlândia (UFU), Av. Pará 1720, Campus Umuarama, Bloco 2T, Uberlândia, MG 38400-902, Brazil.
}

estruturas anatômicas ligada à evolução dos primatas, considerado em estudos sobre a anatomia comparativa entre Cebus libidinosus e outros primatas neotropicais ou provenientes do Velho Mundo, e as modalidades de conhecimento sobre sua anatomia pode representar um fator importante para a sua preservação e proteção quando os animais são levados às clínicas veterinárias após acidentes ou doenças. Em termos de importância veterinária, ás vezes esses animais chegam na clínica médica veterinária após acidentes, necessitando de cirurgia ou tratamento clínico, mas os poucos dados disponíveis sobre a anatomia tem dificultado o procedimento correto. A principal justificativa para os estudos sobre $C$. libidinosus é devido a pouca informação sobre sua anatomia na literatura cientí- 
fica no Brasil e no mundo. Neste trabalho, a distribuição, inervação e os trajetos dos nervos femoral e isquiático do membro pélvico (coxa) de $C$. libidinosus foram estudados e os resultados foram comparados com a literatura sobre a anatomia dos seres humanos, chimpanzés e babuínos. Em geral (Anatomia Macroscópica), o modelo de inervação dos quatro primatas é idêntico, mas em termos específicos, as diferenças nas inervações indicam uma convergência evolucionária em direção à árvore genealógica dos babuínos, dados corroborados por outros estudos comparativos em relação aos mesmos primatas para vasos, músculos e nervos. Em conclusão, a organização dos nervos na coxa de $C$. libidinosus é idêntico ao do babuíno, chimpanzé e homo, mas mais semelhante ao babuíno. As diferenças específicas encontradas indicam uma origem filogenética antiga para $C$. libidinosus e babuínos (dados corroborados por outros estudos).

TERMOS DE INDEXAÇÃO: Anatomia comparativa, macacoprego, Cebus libidinosus, nervos pélvicos, membros pélvicos.

\section{INTRODUCTION}

Studies on the comparative anatomy of mammals, especially those that can and are used in research laboratories, whether clinical or anatomical-surgical, have been a significant issue for many scientific works, which somehow seek to establish probable phylogenetic correlations between the animal studied and man.

Non-human primates have constituted an important group among animals subjected to various studies. Ethological, evolutionary and paleontological studies have revealed changes in anatomical structures linked to the evolution of primates (Tobias 1971, 1995, Holloway 1973, 1995), considered in studies on the comparative anatomy between Cebus libidinosus (C.libidinosus) and other neotropical monkeys or those from the Old World, and the detailed knowledge on their anatomy may represent an important factor for their preservation and protection when the animals are brought to veterinary clinics after accidents or illnesses (Kindlovits 1999).

The genus Cebus has many similarities with other species of primates, including man, especially with regard to anatomy (Carvalho-Barros 2002). These primates are frequent in the South American continent, in areas ranging from Colombia to Venezuela, northern to southern Brazil and northern Argentina (Cabrera 1957, Guerim et al. 2001, Lopes 2004), are not in extinction (Carvalho-Barros 2002), and present easy reproduction in captivity (Cabrera 1957, Guerim et al. 2001).

The behavior, memory, use of tools and encephalization index put the genus Cebus near, in cognitive terms, to chimpanzees in these respects. Comparative anatomical studies on Cebus and chimpanzees corroborate these data in relation to muscles, nerves and vessels in the thoracic members (Marin et al. 2009, Aversi-Ferreira 2009, AversiFerreira et al. 2005a,b, 2006a,b, 2007a,b).

The use of anatomical data to observe the behavior has been possible from works recently published focusing comparative anatomy, as this area is still lacking of data for these primates (Ferreira \& Prada 2001, Carvalho-Barros et al. 2003, Aversi-Ferreira 2009, Aversi-Ferreira et al. 2005a,b, 2006a,b, 2007a,b, Aversi-Ferreira et al. 2010). The dissection method is the most direct for the observation of body structures, because, the anatomical preparations allow the exposure of muscles, and can show their origin, direction and insertion.

The neural system generally allows establishing phylogenetic relationships between species, mainly due to the brain, which defines the size and shape of the skull, being the region of the skeleton of most interest to anatomists, physiologists, and anthropologists (Testut \& Latarjet 1959).

Studies on the peripheral neural system present a high relevance degree due to the innervation of the muscle groups that may be similar or different in the various taxa of primates in order to evaluate their behavior, such as arborous or terrestrial habits. The similarities of innervated muscles in the taxa are one of the characteristics of phylogenetic identity between species (Aversi-Ferreira et al. 2005, 2009).

In terms of veterinary importance, sometimes these animals arrive in the veterinary medical clinics after accidents, needing surgery or clinical treatment, but the little data available on anatomy has impaired the correct proceedings.

The main justification for studies on Cebus is due to little information about the anatomy related to C.libidinosus in Brazilian and worldwide scientific literature, and this neotropical primate has attracted attention due to their encephalization index (Roth \& Dick, 2005), which is higher than that of Old World primates, such as gorillas (Gorilla gorilla) and identical to chimpanzees (Pan troglodytes), and to their complex cultural behavior (Lopes 2004) such as use of tools (Antinucci \& Visalberghi 1986), and the welldeveloped memory (Tavares \& Tomaz 2002). In the Yerkes National Primate Research Center in Atlanta, United States of America, a research on the social behavior of these animals is being carried out (Waal 2005), showing the worldwide interest on this primate. In Brazil, these primates are used in the treatment of people with disabilities or with limited mobility (Auricchio, 1995).

In this work, the distribution, enervation and path of the femoral, obturator and sciatic nerves of the pelvic limb (thigh) of Cebus libidinosus (before known as Cebus apella) were studied and these results were compared with literature on the anatomy of humans, chimpanzees and baboons, associated with behavioral and evolutionary data.

\section{MATERIALS AND METHODS}

In this study, five specimens of adult and healthy Cebus libidinosus (Rylands 2000) from different ages were used as follows: three males and two female with 1-3 kg body weight, black hair and with various brown hue, more commonly dark brown. The animals were donated by the Brazilian Institute of the Environment (IBAMA-GO). The animals were deposited in the anatomical collection from the Federal University of Goiás, 
Catalão campus. This work was previously approved by the institutional committee (Process CoEP-UFG no.81/2008, authorization of the IBAMA no.15275). All animals were killed by lethal injection of sodium pentobarbital, weighed and perfused via abdominal aorta with latex 601-A (Dupot) mixed with red colorant diluted in ammonium hydroxide solution; included in water at room temperature for 10-12 hours and $10 \%$ formaldehyde mixed with $5 \%$ glycerin through femoral vein perfusion for fixation. The animals were conserved on $10 \%$ formaldehyde, in closed opaque box. The nerves were dissected and documented with digital camera (Cannon, 7.1 megapixels). The denomination of structures was based on description for humans (Gray 2000) and other primates (Swindler \& Wood 1973).

\section{RESULTS}

\section{Sciatic nerve}

In the proximal third, the sciatic nerve is located on the belly of the ischiofemoralis muscle, covered by the caudal fibers of the maximum gluteus, and is located above the cranial margin of the biceps femoris muscle. At this point, the sciatic nerve sends many branches to the biceps femoris muscle, semitendinous, semimebranosus and accessory to the ischiofemoral muscle (Fig.1).

In the medium third of the thigh, the sciatic nerve is

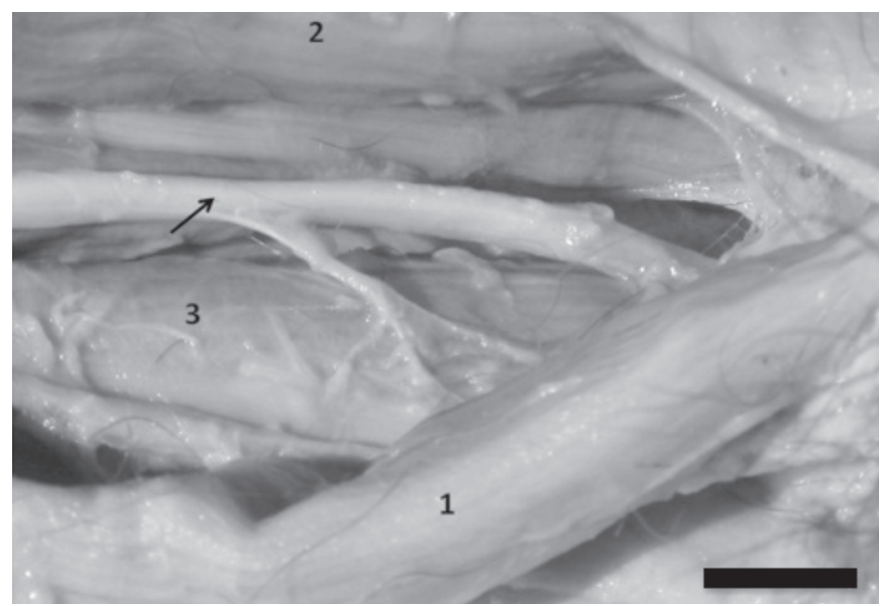

Fig.1. Left tight of Cebus libidinosus, posterior aspect. Sciatic nerve (arrow); (1) semimembranosus; (2) femoral biceps; (3) ischiofemoralis muscles. Scale Bar: $1 \mathrm{~cm}$ found in the muscular channel laterally formed by femoral biceps muscle, medially by the semimebranosus proprius muscle, anteriorly by the ischiofemoralis muscle and posteriorly by the semitendinosus muscle. In the distal third, this nerve is divided into tibial, sural cutaneous medial and common fibular nerves.

In one of the limbs studied (10\%), a branch through the caudal fibers of the glutaeus maximus muscle was observed, also through the cranial fibers of the biceps femori muscle that follows closely to safena magna vein and ends in the caudal fibers of the femoral biceps muscle, where it shows its final branches, the tibial and fibular nerves.

\section{Femoral nerve}

In two specimens, four limbs, the femoral nerve (Fig.2A) penetrates into the thigh behind the inguinal ligament, laterally to the artery and femoral vein. In the proximal third of the thigh, this nerve shows two branches to the sartorius muscle, the saphenous nerve, and two more branches to innerve the vastus intermedius muscle, which penetrates the fibers of the vastus medialis muscle, one branch to the vastus lateralis muscle and four branches to the rectus femoris muscle.

The saphenous nerve (Fig.2B) is large and follows the artery and the femoral vein in its trajectory in the medial aspect of the tight, being covered by sartorius muscle.

In its proximal third, this nerve crosses obliquely the vastus medialis fibers, and in the medium and distal third, the saphenous nerve follows the posterior margin of this muscle.

In general (50\%), the femoral nerves follows the standard description cited above, therefore, there are some variations cited bellow:

1) It penetrates into the thigh behind of inguinal ligament, laterally to the artery and femoral vein; in the proximal third of thigh, it shows the following branches: saphenous nerve, 2 branches to the vastus intermedius muscle that do not cross the vastus medialis fibers, 1 branch to the vastus medialis muscle, 1 branch to the vastus lateralis muscle and 2 branches to the rectus femoris muscle.

2) It exhibits 2 branches to the sartorius muscle; the saphenous nerve shows 2 branches to the vastus intermedius muscle, and no branch penetrates into the fibers of

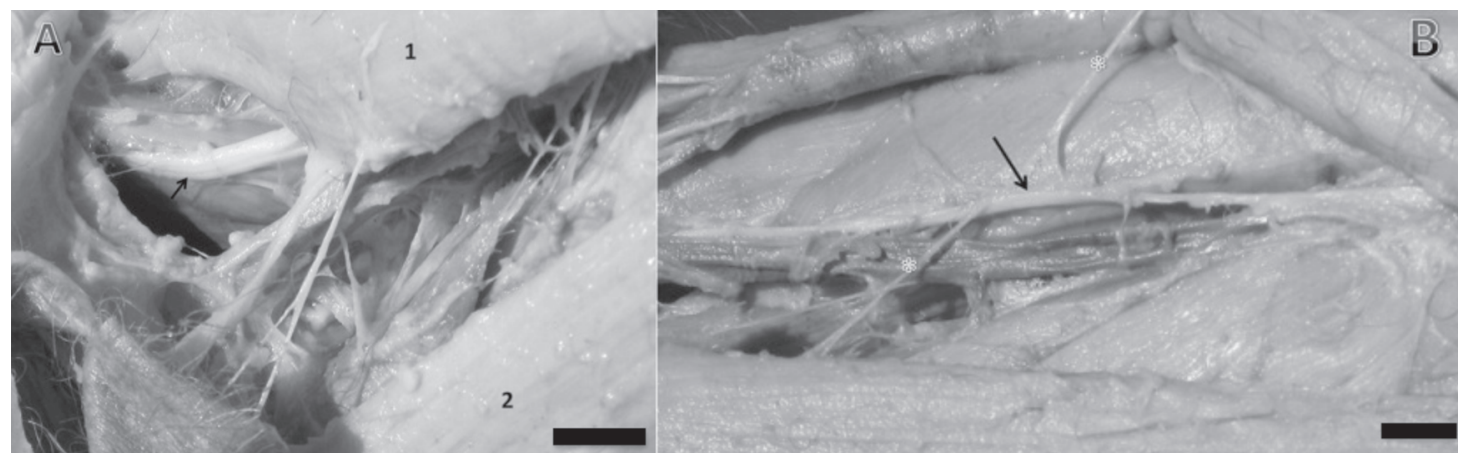

Fig.2. Left tight of Cebus libidinosus, medial aspect. (A) Femoral nerve (black arrow); 1. sartorius; 2. glacilis muscles. (B) Saphenous nerve (black arrow); muscular branches $\left({ }^{*}\right)$. Scale Bar: $1 \mathrm{~cm}$. 
the vastus medialis muscle, 1 branch to each vastus medialis and lateralis muscle, and 2 branches to the rectus femoris muscle.

3) It shows 1 branch to the sartorius muscle, the saphenous nerve, 1 branch to the vastus intermedius muscle, 3 branches to the vastus lateralis muscle, 1 branch to the vastus medialis muscle and 1 branch to the rectus femoris muscle.

4) In two limbs, it shows 1 branch to the sartorius muscle; in the saphenous nerve, 1 branch to the vastus intermedius muscle that do not penetrate into the fibers of the vastus medialis muscle, 1 branch to the vastus lateralis muscle and 3 branches to the rectus femoris muscle.

\section{Obturator nerve}

In six limbs (60\%), after penetrating into the thigh, it is found between the muscular fibers of the origin of pectineus and adductor brevis muscles and follows obliquely to the fibers of the adductos brevis towards the glacilis muscle to innerve it (Fig.3).

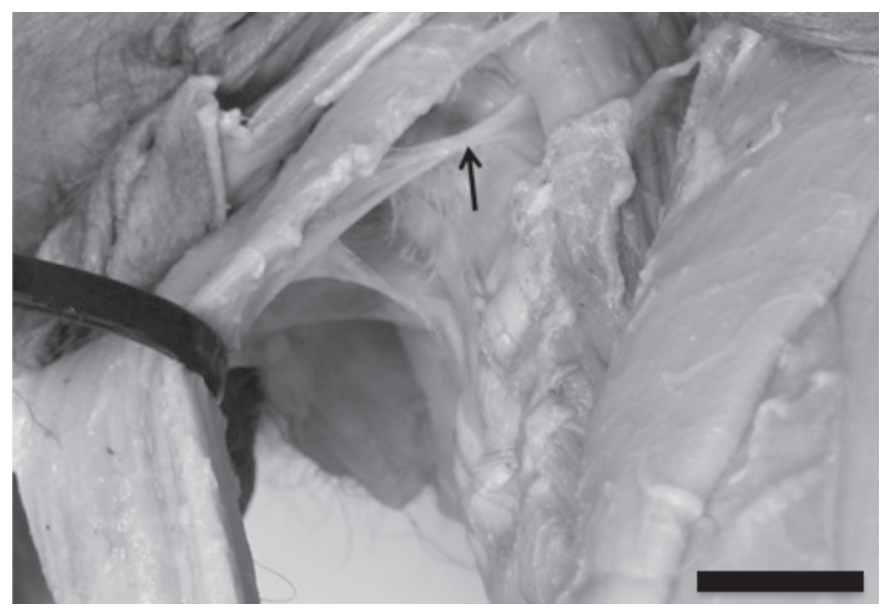

Fig.3. Left tight of Cebus libidinosus., medial aspect. Obturator nerve (black arrow). Scale Bar: $1 \mathrm{~cm}$.
In one limb (10\%), the obturator nerve shows another branch that crosses the adductor brevis muscle and innervates the semimembranosus proprius and adductor magnus muscles. In two limbs (20\%), it shows one branch that crosses the adductor brevis muscle, the adductor magnus muscle and innervates the adductor longus muscle.

In other two limbs (20\%), the obturator nerve shows three branches, 1 branch that crosses the muscular fibers in the origin of the adductor brevis muscle and innervates the adductor magnus muscle; one branch that innervates the adductor magnus muscle; and one branch that crosses the adductor magnus muscle and innervates the adductor longus muscle.

\section{DISCUSSION}

According to Swindler \& Wood (1973), in human, chimpanzee and baboons the sciatic nerve is identical in distribution, enervation and ramification, and the variations cited by these authors are identical to observed in humans (O'Rahilly 1985, Gray 2000). In Cebus libidinosus no variations of final ramification cited to human were observed; the enervation of ischiofemoral muscle is inedited and the adductor magnus muscle is not enervated by sciatic, but by the obturator nerve (Table 1). Nevertheless, the skin enervation, localization and path are identical to others primates here studied (Swindler \& Wood 1973). In all cited species, the sciatic nerve is the largest nerve in the body and gives off articular and muscular branches.

The femoral nerve in $C$. libidinosus does not enervate the pectineus muscle, present different model of localization and number of branches to specimens studied here. For chimpanzees and humans, the femoral nerve has the identical distribution and localization, in baboons, it is located more laterally (Swindler \& Wood 1973), which is identical to $C$. libidinosus.

In all primates, the saphenous nerve is the largest cutaneous branch of the femoral nerve and has identical ge-

Table 1. Comparation of the thigh nerves in Cebus libidinosus, Papio, Pan and Homo sapiens

\begin{tabular}{|c|c|c|c|c|c|}
\hline Nerves & Features & Cebus libidinosus & Papio & Pan & Humans \\
\hline \multirow[t]{2}{*}{$\begin{array}{l}\text { Sciatic } \\
\text { nerve }\end{array}$} & $\begin{array}{l}\text { Innervated } \\
\text { muscles }\end{array}$ & $\begin{array}{l}\text { Biceps femoris, semiten- } \\
\text { dinosus, semimembrano- } \\
\text { sus proprious and aces- } \\
\text { sorius, ischiofemoral }\end{array}$ & $\begin{array}{l}\text { Adductor magnus, biceps } \\
\text { femoris, semitendinosus, } \\
\text { semi-membranosus pro- } \\
\text { prious and acessorius }\end{array}$ & $\begin{array}{l}\text { Adductor magnus, bi- } \\
\text { ceps femoris, semiten- } \\
\text { dinosus, semimembra- } \\
\text { nosus proprious and a- } \\
\text { cessorius }\end{array}$ & $\begin{array}{l}\text { Biceps femoris, semitendi- } \\
\text { nosus, semimembranosus, } \\
\text { adductor magnus. }\end{array}$ \\
\hline & Main branches & Tibial and fibular nerves & $\begin{array}{l}\text { Tibial and fibular common } \\
\text { nerves }\end{array}$ & Tibial and fibular nerves & Tibial and fibular nerves \\
\hline \multirow[t]{2}{*}{$\begin{array}{l}\text { Femoral } \\
\text { nerve }\end{array}$} & $\begin{array}{l}\text { Innervated } \\
\text { muscles }\end{array}$ & $\begin{array}{l}\text { Sartorius, vastus interme- } \\
\text { dius, vastus medialis, vas- } \\
\text { tus lateralis, rectus femo- } \\
\text { ris }\end{array}$ & $\begin{array}{l}\text { Pectineus, sartorius, vas- } \\
\text { tus intermedius, vastus } \\
\text { medialis, vastus lateralis, } \\
\text { rectus femoris }\end{array}$ & $\begin{array}{l}\text { Pectineus (motor fibers), } \\
\text { sartorius, vastus inter- } \\
\text { medius, vastus media- } \\
\text { lis, vastus lateralis, rec- } \\
\text { tus femoris }\end{array}$ & $\begin{array}{l}\text { Sartorius, vastus interme- } \\
\text { dius, vastus medialis, vas- } \\
\text { tus lateralis, rectus femoris, } \\
\text { pectineus (motor fibers) }\end{array}$ \\
\hline & Main branches & Saphenous nerve & Saphenous nerve & Saphenous nerve & Saphenous nerve \\
\hline \multirow[t]{2}{*}{$\begin{array}{l}\text { Obturator } \\
\text { nerve }\end{array}$} & $\begin{array}{l}\text { Innervated } \\
\text { muscles }\end{array}$ & $\begin{array}{l}\text { Adductor brevis, adductor } \\
\text { magnus, adductor longus, } \\
\text { gracilis, semimembrano- } \\
\text { sus proprius }\end{array}$ & $\begin{array}{l}\text { Adductor brevis, adductor } \\
\text { magnus, adductor longus, } \\
\text { gracilis, pectineus }\end{array}$ & $\begin{array}{l}\text { Pectinius, adductor bre- } \\
\text { vis, adductor magnus, } \\
\text { adductor longus, gracilis }\end{array}$ & $\begin{array}{l}\text { Adductor brevis, adductor } \\
\text { longus, gracilis, pectineus } \\
\text { (rare) }\end{array}$ \\
\hline & Main branches & Muscular & Muscular & Muscular & $\begin{array}{l}\text { Muscular and obturator } \\
\text { acessory }\end{array}$ \\
\hline
\end{tabular}


neral characteristic, i.e., it is followed by the femoral artery, but this vessel is thinner in human when compared to others primates (Swindler \& Wood 1973).

The obturator nerve was not described in the thigh by Swindler \& Wood (1973), but in the pelvis. In the thigh of humans, it divides into anterior and posterior branch, which is separated at first by some fibers from obturator externus, and lower down by the adductor brevis muscle (Gray 2000), description identical to $C$. libidinosus only about the part from adductor brevis. In C. libidinosus, there are major variations in the enervation and in branches emission.

In general, the enervation model of the four primates is identical, but specifically, the differences in enervations indicate a convergent evolution from $C$. libidinosus to baboon.

It is a fact that the encephalization index in C. libidinosus is higher than the encephalization index in baboons (Sand 1995), and closer to chimpanzees in behavior, memory and use of tool (Fragaszy et al. 2004).

Since the evolutionary tree of primates was divided about 30 million years ago (Byrne 2000) into New World and Old World primates, separating the ancestral of Cebus from apes and hominids, these data may indicated a important evolutionary aspect due to the occurrence of a divergent and, at the same time, a convergent evolution as for two aspects, tool use, identical to chimpanzee and $C$. libidinosus, one divergent to locomotion; and convergent to locomotion to baboon and $C$. libidinosus, but divergent to tool use (Aversi-Ferreira et al. 2010).

In fact, the anatomical data indicate a identical model of nerves, muscles and vessels closer to baboons than to chimpanzees, except to forearm and hand muscle, that is, the shoulder and arm vessels and nerves model is more identical to baboons, but the models is identical to baboons as for shoulder and arm, but not for forearm and hand, which are more identical to chimpanzees (Aversi-Ferreira et al. 2005a,b, 2006a,b, 2007a,b, Marin et al. 2009, AversiFerreira 2009, Aversi-Ferreira et al. 2010). Nevertheless, both baboons and $C$. libidinosus have tail, climb trees and walk on soil with the four hands most of the times, facts that can justify the anatomical similarities between shoulder and arm muscles.

The fact is that, based on data from anatomic and behavioral comparative analysis, the genus Cebus (New World primate) is closer to chimpanzees (Old World primates) in cognitive terms, but even closer to baboons (Old World primates) according to the anatomy of shoulder and arm structures, therefore, they are closer to chimpanzee as for the forearm and hand structures, and these are important data to evolutionary studies, since there are explanations to these facts so far.

On the other hand, in clinical and surgery terms, and according with data obtained here about the position of the nerves, after normal surgery proceedings, the lateral access to thigh can be identical to dog cited by Ferrigno et al. (2007a,b).

As an indication for surgical route on the medial side, it is important to consider the size of the femoral vessels, proportionally higher in Cebus; also take care with the presence of the saphenous nerve and several muscular branches.

Kindlovits (1999) reports clinical and surgical applications to neotropical primates, including Cebus, but shows no anatomical references as indicative points of access to these proceedings, nor to anamnesis, therefore, A good clinical and surgical work requires correct anatomical data.

Generally, any little anatomical aspect can be found in The Complete Capuchin (Fragaszy et al. 2004), but this publication is focused at the behavior and ecology of Cebus.

In reference to clinical and surgery of Cebus, many anatomical works on thoracic members can be found in specialized literature (Aversi-Ferreira et al. 2005a,b, 2006a,b, 2007a,b, Aversi-Ferreira 2009, Marin et al. 2009, AversiFerreira et al. 2010), but, to pelvic members, there is just one work on the thigh muscle (Sousa et al. 2008), far.

Therefore, further studies on muscles, vessels and nerves of Cebus are still necessary, not only $C$. libidinosus, because this primate has is very common in all Brazilian territory and its presence in the clinical of veterinary medicine is frequent, mainly in universities with partnership with IBAMA, in consequence of trauma caused by accidents; furthermore, new studies will help provide new data to evolutionary comparative studies about these primates.

\section{CONCLUSION}

It can be concluded that the nerve organization in the thigh of Cebus libidinosus is identical to baboon, chimpanzee and humans, but more similar to baboon.

Acknowledgements.- The authors thank the Brazilian Institute of the Environment (IBAMA) for donating the Cebus libidinosus specimens dissected in this study. The authors also thank the anonymous reviewers for their wise and very helpful comments on previous versions of this article.

\section{REFERENCES}

Antinucci F. \& Visalberghi E. 1986. Tool use in Cebus apella: A case study. Int. J. Primatol. 7:351-363.

Auricchio P. 1995. Primatas do Brasil. Terra Brasilis, São Paulo. 168p.

Aversi-Ferreira T.A., Lima-e-Silva M.S., Pereira-de-Paula J., Gouvêae-Silva L.F. \& Penha-Silva N. 2005a. Anatomia comparativa dos nervos do braço de Cebus apella. Descrição do músculo dorsoepitroclear. Acta Sci. Biol. Sci. 27:291-296.

Aversi-Ferreira T.A., Aversi-Ferreira R.A.G.M.F., Silva Z., Gouvêa-eSilva L.F. \& Penha-Silva N. 2005b. Estudo anatômico de músculos profundos do antebraço de Cebus apella (Linnaeus, 1766). Acta Sci. Biol. Sci. 27:297-301.

Aversi-Ferreira T.A., Vieira L.G., Pires R.M., Silva Z. \& Penha-Silva N. 2006a. Estudo comparativo entre os músculos flexores superficiais do antebraço de macaco Cebus e do homen. Biosci. J. 22:139-144.

Aversi-Ferreira T.A., Lima-e-Silva M.S., Pereira-de-Paula J. \& Mata J.R. 2006b. Anatomia comparativa entre os músculos extensores do antebraço de Cebus libidinosus com humanos e outros primatas. R.E.F. 3(2):13-15.

Aversi-Ferreira T.A., Pereira-de-Paula J., Lima-e-Silva M.S., Prado Y.C.L. \& Silva Z. 2007a. Estudo anatômico das artérias do ombro de 
Cebus libidinosus (Rylands, 2000; Primates - Cebidae). Ciênc. Anim. Bras. 8:272-284.

Aversi-Ferreira T.A., Pereira-de-Paula J., Prado Y.C.L., Lima-e-Silva M.S. \& Mata J.R. 2007b. Anatomy of the shoulder and arm muscles of Cebus libidinosus. Braz. J. Morphol. Sci. 24:3-14.

Aversi-Ferreira T.A. 2009. Comparative anatomical description of forearm and hand arteries of Cebus libidinosus. Int. J. Morphol. 27:219-226.

Aversi-Ferreira T.A., Diogo R., Potau J.M., Bello G., Pastor J.F. \& Aziz M.A. 2010. Comparative anatomical study of the forearm extensor muscles of Cebus libidinosus (Rylands et al., 2000; Primates, Cebidae), modern humans, and other primates, with comments on primate evolution, phylogeny, and manipulatory behavior. Anat. Rec. 293:2056-2070.

Byrne R.W. 2000. Evolution of primate cognition. Cognitive Science 24:543-570.

Cabrera A. 1957. Catálogo de los mamíferos de América del Sur. Revta Mus. Argent. Cienc. Nat. "Bernardino Rivadavia", Buenos Aires. 307p.

Carvalho-Barros R.A. 2002. Estudo anatômico dos plexos lombar, sacral e coccígeo do macaco Cebus apella: origem, composição e nervos resultantes. Dissertação de Mestrado em Anatomia dos Animais Domésticos, Faculdade de Medicina Veterinária e Zootecnia, USP, São Paulo, SP. 146p.

Carvalho-Barros R.A., Prada I.L.S., Silva Z., Ribeiro A.R. \& Silva D.C.O. 2003. Constituição do plexo lombar do macaco Cebus apella. Braz. J. Vet. Res. Anim. Sci. 40:373-381.

Ferreira J.R. \& Prada I.L.S. 2001. Nomenclatura proposta para denominar as artérias da base do encéfalo do macaco-prego (Cebus apella L., 1766). Acta Sci. Biol. Sci. 23:635-643.

Ferrigno C.R.A., Schmaedecke A. \& Ferraz V.C.M. 2007a. Abordagem cirúrgica inédita para denervação acetabular em cães. Pesq. Vet. Bras. 27:61-63.

Ferrigno C.R.A., Schmaedecke A., Oliveira L.M., D’Ávila R.S., Yamamoto E.Y. \& Saut J.P.E. 2007b. Denervação acetabular cranial e dorsal no tratamento da displasia coxofemoral em cães: 360 dias de evolução de 97 casos. Pesq. Vet. Bras. 27:333-340.

Fragaszy D.M., Visalberghi E. \& Fedigan L.M. 2004. The Complete Capuchin. Cambridge University Press, Cambridge. 339p.

Gray H. 2000. Anatomy of Human Body. Lea and Febiger. Bartleby. Com., Philadelphia. In: www.bartleby.com/107/. Access in Apr. 2007.
Guerim L, Gazêta G.S., Serra-Freira N.M., Sá L.M. \& Dias J.L.C. 2001. Cebus apella (Primate: Cebidae) as a new host for Fonsecalges johnjadini (Acari: Psoroptidae, Cebalginae) with a description of anatomopathological aspects. Mem. Inst. Oswaldo Cruz 96:479-481.

Holloway R.L. 1973. Endocranial volumes of early African hominids, and the role of the brain in human mosaic evolution. J. Human Evol. 2:449-459.

Holloway R.L. 1995. Toward a synthetic theory of human brain evolution, p.42-60. In: Changeux J.P. \& Chavaillon J. (Eds), Origins of the Human Brain. Clerendon Press, Oxford.

Kindlovits A. 1999. Clínica e Terapêutica em Primatas Neotropicais. Ed. UFJF, Juiz de Fora. 264p.

Lopes R.J. 2004. Gênio da selva. Scient. Am. Brasil 3:24-32.

Marin K.A., Carneiro e Silva F.O., Carvalho A.A.V., Nascimento G.N.L., Prado Y.C.L. \& Aversi-Ferreira T.A. 2009. Anatomy of the nervous of forearm and hand of Cebus libidinosus (Rylands, 2000). Int. J. Morphol. 27:635-642.

O’Rahilly R. 1985. Anatomia Humana Básica. Interamericana, Rio de Janeiro. 473p.

Roth G. \& Dicke U. 2005. Evolution of the brain and intelligence. Trends Cogn. Sci. 9:250-257.

Rylands A.B., Schneider H., Langguth A., Mittermeier R.A., Groves C.P. \& Rodriguez-Luna E. 2000. An assessment of the diversity of new world primatas. Neotropical Primates, Washington, 8:61-93.

Sousa G.C., Menezes L.T., Silva Z., Bernadino Junior R., Lizardo F.B., Facury Neto M.A., Santos L.A. \& Barros R.A.C. 2008. Estudo comparativo da inserção proximal do músculo reto femoral do homem com Cebus apella. Hora da Ciência 1:1-21.

Swindler D.R. \& Wood C.D. 1973. An Atlas of Primate Gross Anatomy. University of Washington Press, Washington. 370p.

Tavares M.C.H. \& Tomaz C.A.B. 2002. Working memory in Capuchin Monkeys (Cebus apella). Behav. Brain Res. 131:131-137.

Testut L \& Latarjet A. 1959. Tratado de Anatomia Humana. Salvat, Barcelona. 766p.

Tobias P.V. 1971. The Brain in Hominid Evolution. Columbia University Press, New York.170p.

Tobias P.V., Changeux J.P. \& Chavillon J. 1995. Origins of the Human Brain. Clarendon Press, Oxford. 321p.

Waal F.B.M. 2005. Como os animais fazem negócios. Scient. Am. Brasil 4:68-75. 